Review Essay

\title{
Anarchism mainstreamed? On recent trends, challenges and opportunities in anarchist scholarship
}

Contemporary Political Theory (2021). https://doi.org/10.1057/s41296-021-00532-7

Carissa Honeywell, Anarchism, Polity Press, Cambridge, 2021, 168pp., ISBN 9781509523917

Ruth Kinna, The Government of No One: The Theory and Practice of Anarchism, Pelican, London, 2019, 432pp., ISBN 9780141984667

Carl Levy and Saul Newman (Eds.), The Anarchist Imagination: Anarchism encounters the humanities and the social sciences, Routledge, London and New York, 2019, 278pp., ISBN 9781138782761

From Occupy to mutual aid in a pandemic time, from Rojava to the Invisible Committee, ideas associated with the anarchist cultural constellation have seen a recent spike in popularity amongst scholars and activists alike (Rodgers Gibson, 2019). Namely, the last decade has witnessed a significant increase in scholarly attention to anarchist political theories. An index of this phenomenon is the growing number of monographs and edited collections on anarchism published by mainstream publishers. In fact, editorial production on anarchism has always been large and relentless, but confined to specific types of publications and specialised publishers.

Three recent examples of the development of scholarly interest in this subject are Carissa Honeywell's Anarchism, Ruth Kinna's The Government of No One and Saul Newman and Carl Levy's edited volume on The Anarchist Imagination. They tackle different dimensions of anarchism, introducing the reader to anarchist praxis (Honeywell), historical-conceptual debates (Kinna) and analytical uses to enrich social and human sciences (Newman and Levy). Overall, they generate a thoughtprovoking and fine-grained image of the contemporary developments and challenges characterising anarchism, warranting an attentive critical reading. Despite a slight tendency towards anglocentrism and a possible inclination to epistemic appropriation, they have the potential to help fuel scholarly interest in anarchism.

(c) 2021 The Author(s), under exclusive licence to Springer Nature Limited. 1470-8914 Contemporary Political 
Honeywell's Anarchism provides a critical engagement with specific themes within anarchism, also spelling out some of the commonplaces which thrive around this subject (e.g. its nihilistic, destructive and self-defeating nature). Each chapter deals with a dimension of contemporary anarchist praxis and its underpinning principles.

The Introduction and Chapter 1 provide firstly a meta-theoretical definition and then a minimal history of anarchism. 'Anarchism' here is defined as 'a connected series of attempts to respond to [harms, violence, collapsing resources] from an egalitarian and anti-authoritarian perpsective' (p. 1), which coalesce around the idea that 'coercive political hierarchy ... is a choice' (p. 3). Having defined these loose conceptual boundaries, Chapter 1 lays out an overview of a good deal of anarchist canonical theories/theorists from the late 1800s to the 1990s.

Chapters 2, 3 and 4 consist of three case studies on contemporary anarchist praxis. Honeywell describes some of the fundamental anarchist values using a ground-up approach, that is, bringing to the fore a number of possible examples of practices which embody those values. The first focuses on the 'Food Not Bombs' (FNB) mutual aid network elevated to a paradigm of the centrality of relational dynamics (e.g. reliability, interdependence and trust, and their links with freedom) within anarchism. FNB is an all-volunteer global food-sharing movement dedicated to non-violent direct action. Its normative horizon is to promote a transition to selfgoverned communities emphasising a politics of survival and resistance to neoliberalism by 'decommodifying food and politicizing hunger' (p. 37).

Chapter 3 on harm reduction uses 'Prevent Point' as a case study. This grassroots initiative aimed to stop the spread of AIDS in the 1980s, proposing a disease cure-and-prevention model that is now referred to as 'harm reduction'. This non-stigmatising and non-punitive approach is considered by Honeywell as an expression of non-dominating forms of relating (pp. 66-67). Honeywell highlights the resonance between the early harm reduction movement, which emerged as a set of illegal voluntary self-help activist practices, and the anarchist key concept of prefiguration (p. 67). Prefigurative politics insists on how present actions define future outcomes, on the normative alignment between ends and means. Honeywell advocates an understanding of prefiguration that matches reform in the present with radical transformation in the future, using drug addiction as an example of the embodied political effects of the dislocation of social relationships (p. 75).

The next chapter unpacks the idea of justice-beyond-punishment, based on the premise that punishment does not address the social needs of those who engage with crimes whilst working as one of the primary justifications of the state monopoly of violence (p. 97). Here the case study is the 'Empty Cage Collective', an anarchist group working on prisoner support with a wider prison abolition agenda. They argue for non-violent ways to secure the safety of individuals and communities and more 'restorative' routes to respond to harm than inflicting further harm (p. 98) and that these alternative options are linked to wider struggles for what

(C) 2021 The Author(s), under exclusive licence to Springer Nature Limited. 1470-8914 Contemporary 
W.E.B. Dubois called 'abolition democracy'. Honeywell recalls the contributions of anarchist criminology integral to a wider transformative aspiration - broadening the range of conflicts and harms that a community can address though dialogue, whilst recognising that an a conflict resolution framework is not always applicable (e.g. partner abuse and sexual assault) (p. 123). The conclusions wrap up the argument, emphasising the key point of demilitarising our life at a granular level and rethinking our relationships in a prefigurative way.

Ruth Kinna's The Government of No One is essentially a contemporary singleauthored textbook on anarchism, both in terms of style (uniform and factual) and content (dense and wide-ranging). Similar to Honeywell, it functions as an introduction to anarchism's myths and realities, focusing on both thought and practice (p. 7).

The first chapter discusses anarchist traditions, in an attempt to find a compromise between the idea of anarchism as an ideological monolith with neat boundaries and the idea that anarchism is a whole host of disparate things loosely connected by some values. It then describes the main aim of the state as an apparatus to preserve the unequal distribution of private property through police and prisons and the following demonisation and criminalisation of anarchist dissent.

Chapter 2 shifts from historical mapping to a conceptual endeavour: charting anarchist cultural critiques to explain the constancy of subjugation (p. 56), a classical anarchist theme. The two main objects of this cultural analysis are the anarchist critique of domination and one of its rejoinders - education. Domination is 'a diffuse kind of power, embedded in hierarchy - pyramidal structures, pecking orders and chains of command - and in uneven access to economic or cultural resources' (pp. 59-60). Kinna sees the rejection of domination as the unifying element across anarchist struggles and transformative education, understood as 'an approach to life, tapping into long-established conventions that emphasize processes of socialization and moral development as well as learning or knowledge acquisition' (p. 84), as a key tool to overcome domination.

Chapter 3 to some extent continues the previous one, discussing practices different from education to defy domination linked with two debates within anarchism, the first fairly dated (violence and organisation) whilst the latter more recent (class and intersectionality). Kinna argues that by the 1800s anarchists saw violence as sometimes integral to the idea of 'propaganda by the deed', others as a product of the very capitalist brutalisation of resistance (p. 121). This section provides a perceptive historical analysis of the multiple developments within anarchism that originated around the discussion on the role of violence. Yet, history always has a bearing on the present, and in fact anarchists still argue about violence, and debate about tactical diversity or black blocs are an expression of this recurrent theme (p. 133). 
Regarding classist oppression, Kinna states that its critique within anarchism is only partly aligned with Marxist analysis, since the latter is seen as underpinned by a naive 'thesis of progress' and historical determinism (p. 151), and its idea of class is totalising and does not include all the oppressed (p. 154). This discussion is then combined with intersectionality. A large body of recent anarchist thinking and practice has adopted, mainly from Black feminists, an intersectional approach to oppression. However, there are different opinions on how to theorise the relationships between class and non-class oppression and on the type of action which should follow intersectional critique (p. 157). The book's wager here is that all forms of oppression are on the same level of intensity and that focusing only on socio-economic class, means giving in to a bourgeois diversion strategy.

Chapter 4 discusses 'anarchist constitutions', that is, anarchists' efforts to solidify their values by translating them into constitutional charters. The chapter then describes some anarchist utopian visions, as less solidified visions of anarchist forms of communal life. It then reflects on anarchist takes on democracy, both in terms of critique of merely procedural conceptions of democracy and in terms of anarchist/communalist democratic visions and arrangements. It finally includes a short discussion on consensus decision-making, its basic values, rules and applications.

The last chapter explores future 'prospects' for anarchism. It begins with assessing anarchist ideas about success and failure, reframing them as issues of capacity, resilience and endurance. Kinna then reflects on the purported impossibility of overcoming the state, proposing as an alternative the idea of 'anarchisation'. This consists of strategies of change which aim at altering, although partially, social arrangements according to anarchist principles, e.g. by bridge-building between anarchists and non-anarchists, or through acts of transgression and disobedience (p. 265). The book does not have a conclusion, but a final section on anarchists' biographies, a tribute to those who often have sacrificed their lives to anarchist ideals.

Levy and Newman's The Anarchist Imagination is significantly different from Honeywell's and Kinna's books for two main reasons. Firstly, this is an edited collection. Secondly, it pursues a highly specific aim: to re-discover either the anarchist conceptual and normative roots of certain disciplinary domains or to offer some anarchist analytical tools which are used or could be used by scholars within social and human sciences.

The Introduction by Levy starts with a brief reflection on the meaning of the key theoretical construct 'anarchist imagination'. Referring to C. Wright Mills' well known concept of 'sociological imagination', Levy describes the anarchist imagination as a fluid range of 'anarchist methodologies and theoretical constructs [which] have influenced the humanities and the social sciences' (p. 4). The anarchist element refers to 'moments of madness', contingency and imagination in doing research, highlighting the normative drive of such intellectual-political 
endeavour. Anarchism here appears as a sort of historical epistemic invariant insofar as it represents either the friend or the foe of social scientists as different as Marx, Spencer, Weber, Gramsci and Mills.

The first half of the book mainly tackles anarchist imagination in political theory and political sciences, broadly conceived. Bamyeh's chapter demarcates between self-conscious anarchism and organic anarchism, using the overthrow of the Mubarak regime in Egypt as a case study (p. 30). The anarchist imagination here is mobilised to make sense sociologically of the Arab spring, providing a ground-up approach to structural forms of resistance and mobilisation which could be applied to the sociological study of other social movements. The following chapter (by Kazimi) is an anarchist critique of the concept of 'anarchy' within International Relations. Here the anarchist imagination works as a searing critique of that disciplinary field (p. 42). This ties well with Rossdale's chapter which provides an anarchist critique of critical security studies, and namely of the restrictive concept of security therein, suggesting to widen its scope from an anarchist perspective, by connecting security to mutual aid networks and not to violent state agencies (p. 62).

Newman's chapter looks into post-structuralist political and social theorists' indirect contributions to anarchism, toward an ethical politics which contests sovereignty from different angles (p. 81) whilst Kinna's work slightly shifts the focus from European political theory to Anglo-American political science (p. 95). The main point here is that methodological choices integral to the very emergence of that disciplinary field are at odds with anarchist values and that a significant intellectual effort is required to anarchise not only the broad field of AngloAmerican political science (Kinna) but also specific political theories of anarchism developed therein (Newman). Jeppesen's chapter highlights how anarcho-feminists have contributed toward redefining the parameters for the understanding of power and oppression, breaking the private-public divide (p. 110). Heckert ideally closes this rather homogeneous part of the book, providing a meditation on 'loving politics' and on politics as a relationship. This is a profoundly trans-disciplinary intellectual effort to fertilise political theory mainly using an ontological concept of anarchism as a catalyst for change (p. 132).

The second part of the book includes contributions from a variety of disciplines mainly from the social sciences realm. Ince's chapter engages with geography from an anarchist perspective (p. 146) focusing on the conceptualisation of spaces as networked patterns of autonomy wherein the fight against the neo-liberal deregulation and enclosures take place, whilst working toward communal spaces. Along approximately the same disciplinary lines, Ranmath provides a sympathetic critique of postcolonial studies, putting forth an anti-colonialist normative orientation and suggesting this should be adopted by postcolonialist scholars (p. 163). Loizidou's chapter moves onto an anarchist critique of law, interrogating statist and critical conceptions of law from an anarchist perspective (p. 181), providing a critique similar to Suissa's analysis of the normative deterioration of 
state-led education. Christoyannopoulos focuses on religious studies, reflecting on the actual and possible entanglements between religion, the study of religion and anarchism (p. 210) whilst Antliff's final chapter engages with the role of aesthetics in anarchism's politics (p. 229). The book's conclusion, written by Levy, takes up some of the recurrent challenges raised and/or experienced by the authors, particularly around the cultural appropriation of anarchism (p. 240).

The three attempts at critically engaging, mapping and re-discovering anarchism reviewed above, should contribute to fuelling the scholarly interest around this subject, for a number of reasons. Firstly, they all provide a sustained unpacking of the negative myths surrounding anarchism, through a passionate yet balanced engagement with its sources, themes and challenges. They persuasively argue that in contemporary anarchist anthropology there is no space for the naive humanitarianism which characterised classical anarchism, whilst contesting Hobbesian anthropological pessimism by appealing to the primacy of the social bond and interconnectedness; that anarchism does not equate with violence but with cooperation and solidarity; and that anarchism is not an after-dinner utopia but a normative horizon daily enacted throughout the world by a diverse range activists, scholars and people. The three books all combine philosophical anarchism with anarchism as a form of political activism whilst adopting a cultural antifoundationalist epistemic stance, problematising the boundaries between microand macro-political action and thought. From this angle, they demonstrate how anarchist principles are relevant to contemporary global political struggles around the distribution of resources, combining ethical engagement with political struggles.

Some possible issues associated with those intellectual efforts should be noted as well. The two main ones are a looming epistemic appropriation and anglocentrism. Regarding the former, this applies to the examples of anarchist political and academic practice discussed within the three books. There seems to be a shared tendency to label as 'anarchists' a variety of disparate organisations, groups and scholars based on their broad resonance with anarchist values. As a result, the anarchist universe appears relentlessly expanding, somehow borderless. Although this operation may exemplify the creativity of anarchist thought, it is not without risks. The first is that properties connoting anarchism become minimal, to the point that anarchism appears a catch-word for capturing an extensive range of progressive forces: everything non-dominating is anarchism. In this way, it seems that a sort of legitimation is sought out: anarchism is everywhere and everytime, and not a dark niche as sometimes it is derogatorily described. Yet, this epistemic operation goes at the expense of conceptual clarity.

A second risk is ethical: one is left wondering whether actions, concepts, interpretations, stories generated by those organisations/actors labelled as anarchist end up being detached from their context as a result of that labelling. This 'epistemic detachment' may cause the expansion of anarchist knowledge by 
incorporating those new epistemic resources, however, there remains a risk of obscuring the unique context-specific participatory role of contributors 'in the process of knowledge' (Davis, 2018, p. 705). Those groups', actors' and scholars' voices, although elevated to paradigms of anarchism, sometimes appear as rather constrained by their instrumental incorporation in a formal recognised epistemic horizon (i.e. anarchism).

Regarding anglocentrism, although authors do draw either on stories or contributors from outside the anglosphere, there remains an emphasis on anglophone experiences, writers and on heavily anglicised concepts, e.g. community. These are not neutral descriptors but culturally sensitive constructs often underpinned by specific cognitive models (Levisen, 2018) which would require a more open self-reflexive problematisation.

These works could possibly represent a tendency in expanding the boundaries of anarchism as a combination of political theory and practice. For this reason, it becomes urgent to reflect on 'which anarchism' is espoused by those authors despite their effort to honour the diversity integral within the anarchist cosmos. Overall, there seems to be a preference for 'small-a' anarchism only normatively classical but anthropologically post-anarchist, largely social-communist and certainly anti-capitalist. Anarchism largely emerges as a normatively laden style of reasoning instantiated in convergent practices toward anarchisation. Here, mainstreaming anarchism means mainstreaming this anarchism.

We are very far from an actual academic establishment of anarchism, and it is difficult to say whether this will ever be possible (or desirable). Whilst those intellectual endeavours to increase the attention around this fluid universe could be welcomed favourably by anarchist political theorists, there are risks integral to such possible mainstreaming. The dilemma is to balance those risks against the bleak alternative space to which academic anarchism has relegated itself (or perhaps has been relegated) to for a very long time - self-defeatist marginality. May the endeavour to engage with bottom-up experiences, map long-term historical development, and re-discover unthought cultural connections (as Honeywell, Kinna, Newman and Levy have done) contribute toward a self-reflexive and prefigurative development of anarchism within academia.

\section{References}

Davis, E. (2018) On Epistemic Appropriation. Ethics 128: 702-727.

Levisen, C. (2018) Biases We Live By: Anglocentrism in Linguistics and Cognitive Sciences. Language Sciences 76: 1-13.

Rodgers Gibson, M. (2019) The Failure of the State and the Rise of Anarchism in Contemporary Antisystemic Praxis. New Proposals: Journal of Marxism and Interdisciplinary Inquiry 10(1): 58-63. 
Publisher's Note Springer Nature remains neutral with regard to jurisdictional claims in published maps and institutional affiliations.

Giuseppe Maglione

University of Kent, Canterbury CT2 7N, UK g.maglione@kent.ac.uk 